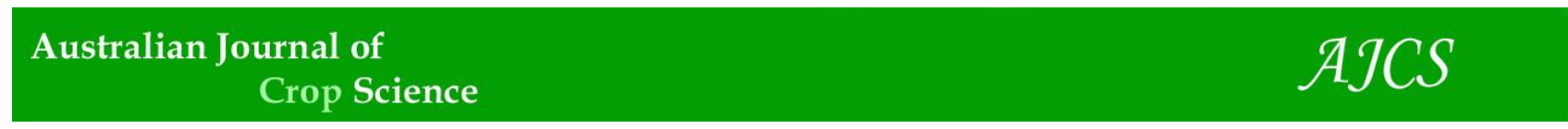

AJCS 11(02):199-205 (2017)

ISSN:1835-2707

doi: 10.21475/ajcs.17.11.02.p269

\title{
Effect of ABA on colour of berries, anthocyanin accumulation and total phenolic compounds of 'Rubi' table grape (Vitis vinifera)
}

\author{
Francisco José Domingues Neto ${ }^{1}$, Marco Antonio Tecchio ${ }^{1}$, Adilson Pimentel Junior ${ }^{1}$, Bruna Thais \\ Ferracioli Vedoato ${ }^{1}$, Giuseppina Pace Pereira Lima ${ }^{2}$, Sergio Ruffo Roberto ${ }^{3}$
}

\author{
${ }^{1}$ Department of Horticulture, São Paulo State University “Júlio de Mesquita Filho", Faculty of Agricultural \\ Sciences (FCA), José Barbosa de Barros, $n^{0}$ 1.780, ZIP: 18.610-307, Botucatu, SP, Brazil \\ 'Department of Chemistry and Biochemistry, São Paulo State University “Júlio de Mesquita Filho", Institute of \\ Biosciences (IBB), Dr. Antônio Celso Wagner Zanin, s/n, ZIP: 18.618-689, Botucatu, SP, Brazil \\ ${ }^{3}$ Department of Agronomy, Londrina State University, Celso Garcia Cid Road, km 380, ZIP 86.057-970, \\ Londrina, PR, Brazil
}

\section{*Corresponding author: fjdominguesneto@hotmail.com}

\begin{abstract}
The color of the berry grapes is due to existence of anthocyanins and their accumulation seems to be regulated, at least in part, by abscisic acid. Therefore, exogenous applications of this regulator may increase the anthocyanins concentration in the grapes skin. The objective of this study was to evaluate the effect of abscisic acid on the color of berries and in the anthocyanin accumulation and total phenolic compounds of 'Rubi' grapes. The 'Rubi' grape (Vitis vinifera) variety was studied in the sixth year of production. The experimental design was randomized blocks, with 4 treatments and 6 replications. The treatments consisted of isomer concentrations of $(S)$-cis-abscisic acid ( $S$-ABA), as follow: Control $\left(0 \mathrm{mg} \mathrm{L}^{-1}\right) ; 400 \mathrm{mg} \mathrm{L}^{-1} \mathrm{de} S$ - ABA at the beginning of the maturation (BM); 400 $\mathrm{mg} \mathrm{L}^{-1}$ at $\mathrm{BM}+200 \mathrm{mg} \mathrm{L}^{-1}$ at 25 DAFA (25 days after the first application) and $400 \mathrm{mg} \mathrm{L}^{-1}$ in $\mathrm{BM}+400 \mathrm{mg} \mathrm{L}^{-1}$ at $25 \mathrm{DAFA}$. The berry bunches were sprayed in the morning, using costal sprayer providing full and uniform coverage. The colorimetric characteristics were determined with colorimeter obtaining the following variables: luminosity, saturation, hue angle and color index. The fresh mass, length and width of bunch (berries and stems), number of berries per bunch, soluble solids, titratable acidity, soluble solids/acidity ratio, $\mathrm{pH}$, reducing sugars, anthocyanins, and phenolic compounds were evaluated. The abscisic acid (S-ABA) promoted the physical characteristics of the bunch and berries slightly with no effect on the stems. However, it triggered significant increase in soluble solids content and in the soluble solids/acidity ratio. It also increased the anthocyanin and total phenolic compounds, especially when applied twice, regardless of the concentration, in addition to improve color attributes. It is recommended the application of $400 \mathrm{mg} \mathrm{L}^{-1}$ at $\mathrm{BM}+200 \mathrm{mg} \mathrm{L}^{-1}$ at 25 DAFA can be useful to increase anthocyanin and total phenolic and to improve color attributes.
\end{abstract}

Keywords: biochemistry; color index; S-ABA; plant physiology; Vitis vinifera $\mathrm{L}$.

Introduction

The viticulture is one of the most important fruit crops in Brazil, being cultivated in the states of Rio Grande do Sul, Pernambuco, São Paulo, Paraná, Santa Catarina, Bahia, Minas Gerais, Goias and Ceará, contributing to an annual production of $1,388,859$ tons of grapes, in 78,450 hectares. Out of this total, 158,781 tons, i.e. $11.43 \%$ is produced in the State of São Paulo, in 8,092 hectares of harvested area (Agrianual, 2015). In 2014, the state of São Paulo produced 158,781 tons of grapes, staying in third position in the national context, behind only Rio Grande do Sul and Pernambuco (Agrianual, 2015). São Paulo state stands out as the second national producer of table grapes. The 'Rubi' table grape (Vitis vinifera L.) arose from a somatic mutation of 'Italia' grape, having the pink berry color, the only difference of the cultivar with its origin (Terra et al., 1998). However, the high incidence of rainfall and the low thermal amplitude during the grapes coloring and maturation cause problems to reach optimal maturation indexes (Gardin et al., 2012). Therefore, the best color development occurs with the alternation of daytime and nighttime temperature (Pommer et al., 2003). The grape color is related to the anthocyanin accumulation and pigments that give color to fruits, flowers and vegetables (Ribichaud and Noble, 1990). The accumulation of anthocyanins starts from veraison (the onset of grape ripening) and is responsible for the intensity of the color of berries and appears to be regulated, at least in part, by abscisic acid (ABA) (Hiratsuka et al., 2001; Ban et al., 2003; Owen et al., 2009). In some areas, ethephon is usually applied to red-colored table grapes to improve berry color, but this effect is not consistent. In addition, this treatment can cause berry softening, which reduces the value of exported grapes (Roberto et al., 2013). Thus, other cost-effective management practices capable of enhancing berry color without causing excessive softening need to be identified. 
The pioneer studies performed with application of $\mathrm{ABA}$ in grape hybrids like 'Kyoho' and 'Olimpia' (Vitis vinifera $\times$ Vitis labrusca) evidenced an increase in the concentration of the anthocyanins in skins (Lee and Tomana, 1980; Kataoka et al., 1982; Matsushima et al., 1989; Han et al., 1996). It is known that the anthocyanin expression depends on internal factors such as $\mathrm{ABA}$, which promotes the transmission effect of MYB1A protein. This protein is in charge to regulate the genes involved in the biosynthetic route of anthocyanin of colored grapes (Jeong et al., 2004).

Historically, the ABA's production cost was too high and its use had not been justified in agriculture; however, the recent improvement in the production methods of the isomer $(S)$-cis-abscisic acid (S-ABA), through the fungus Botrytis sp., has made it efficient to the point to be reconsidered as potential in viticulture (Cantín et al., 2007; Peppi et al., 2007; Koyama et al., 2015). The $S$-ABA recently demonstrated its efficiency in the anthocyanins accumulation in the peel of several grapes cultivars in Brazil, such as 'Benitaka', 'Crimson Seedless' and 'Isabel' (Roberto et al., 2012; Leão et al., 2014; Yamamoto et al., 2015a,b).

The objective of this study was to evaluate the effect of treatments consisted of different concentrations of $S$-ABA at different times over the final phase of ripening after veraison on 'Rubi' table grape, aiming to increase the accumulation of anthocyanins, phenolic compounds and color of berries.

\section{Results and Discussion}

\section{Physical aspects of bunches, berries and stems of grape}

There were no significant differences among the treatments for the length of the bunch, berries and stems, width of the berries and stems, fresh mass of the stems and number of berries per bunch (Table 1). In the experiment conducted by Koyama et al. (2014b) with the application of $S$-ABA on 'Isabel' grape and by Roberto et al. (2013) in 'Rubi' table grape, no significant differences were found for the mass and diameter of berries and mass and length of bunch. For the 'Redglobe' grape subjected to implementation of $S$-ABA, Peppi et al. (2007) also found no differences for the mass of berries.

There was significant effect for fresh mass and width of the bunch and fresh mass of the berries (Table 1). For these variables, the largest values were obtained after treatment with two applications of $S$-ABA $\left(400 \mathrm{mg} \mathrm{L}^{-1}\right.$ at the beginning of the maturation $(\mathrm{BM})+200 \mathrm{mg} \mathrm{L}^{-1}$ at 25 days after the first application (25 DAFA).

\section{Physicochemical aspects of Must (freshly pressed fruit juice)}

Regarding the chemical characteristics of Must (freshly pressed fruit juice), significant differences were found for the content of soluble solids (SS), titratable acidity (TA) and relation soluble solids/acidity (SS/TA) (Table 2). In the treatments with the application of $S$-ABA the highest values were observed for the content of SS, after application of 400 $\mathrm{mg} \mathrm{L}^{-1}$ in $\mathrm{BM}+400 \mathrm{mg} \mathrm{L}^{-1}$ at 25 DAFA stood out, with 13.9 ${ }^{\circ}$ Brix, differing from the control $\left(12.3^{\circ}\right.$ Brix $)$.

The application of $S$-ABA provided smaller TA of grape Must, mainly with the concentration of $400 \mathrm{mg} \mathrm{L}^{-1} \mathrm{BM}+200$ $\mathrm{mg} \mathrm{L}^{-1}$ at 25 DAFA. Koyama et al. (2014b) verified that the lowest TA of grape must 'Isabel' was obtained with the concentration of $400 \mathrm{mg} \mathrm{L}^{-1}$ of $S$-ABA, regardless of the application season.
For the ratio SS/TA, the treatments that received two applications, regardless of the concentration, showed the largest values (25.0 and 25.2), compared to control (18.3)., Koyama et al. (2014b) found that the application of $S$-ABA provided an increase in the SS content and consequently SS/TA of 'Isabel' grape. Cao et al. (2010), observed that the application of $S$-ABA provided an increase in the SS content in 'Kyoho' grape. The ratio of SS/TA is related to the fruit taste; whereas the larger it is, the more pleasant the taste should be (Chitarra and Chitarra, 2005). The treatments with $S$-ABA application resulted in fruits with better quality, evidenced by higher values of this ratio.

For the $\mathrm{pH}$ and reducing sugars (AR), no significant differences were found between treatments (Table 2). The $\mathrm{pH}$ ranged from 3.4 to 3.5 between the treatments, while the reducing sugars varied from 10.3 to 11.9 .

\section{Colorimetric characteristics of grape's berries}

Significant differences were found for the colorimetric variables and characteristics such as berries: luminosity $\left(L^{*}\right)$, saturation $\left(C^{*}\right)$, hue angle $\left(h^{\circ}\right)$ and color index (CIRG) (Table 3 ). It was found that the treatments with the application of $S$ ABA, independent of the concentration, showed lower values for the luminosity (30.4 to 30.5), indicating that the berries of 'Rubi' grape submitted to these treatments presented darker color. It was observed a higher average of $L^{*}$ for the control (37.0), indicating that control berries (not treated) presented lower color intensity compared to treated ones, i.e. showed tendency to green color, undesirable characteristic for the grape 'Rubi' grape. Similar results were found in the 'Rubi' grape by Roberto et al. (2013) and in the 'Red Globe' grape by Peppi et al. (2007).

For the variable Chroma $\left(C^{*}\right)$, that defines the color saturation, significant differences were observed. The treatments with application of $S$-ABA presented the lowest values (9.2 to 9.4), i.e. less saturated; while the control presented saturation of 13.7. The $S$-ABA also reduced the $L^{*}$ and $C^{*}$ in 'Isabel' grape (Koyama et al., 2014b), 'Benitaka' (Roberto et al., 2012) and 'Flame Seedless' (Peppi et al., 2006; Peppi and Fidelibus, 2008).

In relation to the variable hue angle $\left(h^{\sigma}\right)$, significant variation was obtained, whereas the highest value was reached with the application of $S$-ABA with concentration of $400 \mathrm{mg} \mathrm{L}^{-1}$ in IM $+200 \mathrm{mg} \mathrm{L}^{-1}$ at 25 DAFA. On the other hand, Roberto et al. (2012) did not observe significant differences in variable $h^{o}$ for grape 'Benitaka'. The same was observed by Koyama et al. (2014a) to grape 'Isabel'. In the experiment conducted by Roberto et al. (2013) differences were found in the variable $h^{o}$ in 'Rubi' grape. However, the $S$-ABA application presented lower values than the control. These differences in results, involving application of $S$-ABA can be explained by the management of the vineyard, grape cultivar and edaphoclimatics conditions among other factors. There was a significant difference for the variable color index (CIRG), verifying that the $S$-ABA, independent of concentration, resulted in larger values (2.9 to 3.1), differing from the control (1.8). Similar results were found in the grape 'Benitaka' (Roberto et al., 2012) and 'Rubi' grape (Roberto et al., 2013). The highest color index of berries is a great variable to evaluate the effect of $S$-ABA on the color of the grapes, because it shows that when the grape 'Rubi' reaches its full natural maturity. In this case, the color uniformity across the surface of the berries does really not occur in control treatment. As it is a fine cultivar grape for table, the color is crucial to obtain the best marketing price, since consumers are attracted by the pink color of berries, because 
Table 1. Fresh mass (FM), length (LEN) and width (WID) of the bunch, berries and stems and number of berries per bunch of the grape 'Rubi', subjected to the application of the abscisic acid (S-ABA). São Miguel Arcanjo, SP, Brazil, 2014/2015.

\begin{tabular}{|c|c|c|c|c|c|c|c|c|c|c|}
\hline & \multicolumn{3}{|c|}{------------ BUNCH ------------- } & \multicolumn{3}{|c|}{ - } & \multicolumn{4}{|c|}{-------- STEM --------- } \\
\hline Treatments $\left(S\right.$-ABA mg L $\left.{ }^{-1}\right)$ & $\mathrm{FM}(\mathrm{g})$ & LEN $(\mathrm{cm})$ & WID $(\mathrm{cm})$ & $\mathrm{FM}(\mathrm{g})$ & $\mathrm{LEN}(\mathrm{cm})$ & WID $(\mathrm{cm})$ & $\mathrm{FM}(\mathrm{g})$ & $\mathrm{LEN}(\mathrm{cm})$ & $\mathrm{WID}(\mathrm{cm})$ & $\mathrm{N}^{\circ}$ berry/ bunch \\
\hline Control (0) & $926.2 \mathrm{~b}$ & 24.0 & $16.2 \mathrm{~b}$ & $10.7 \mathrm{~b}$ & 3.0 & 2.5 & 17.7 & 18.9 & 12.4 & 85 \\
\hline $400(\mathrm{BM})$ & $1033.0 \mathrm{ab}$ & 24.4 & $17.2 \mathrm{ab}$ & $12.1 \mathrm{ab}$ & 3.8 & 2.6 & 17.1 & 19.4 & 13.0 & 84 \\
\hline $400(\mathrm{BM})+200(25 \mathrm{DAFA})$ & $1103.8 \mathrm{a}$ & 24.8 & $18.7 \mathrm{a}$ & $12.8 \mathrm{a}$ & 3.9 & 2.6 & 17.1 & 19.6 & 13.5 & 86 \\
\hline $400(\mathrm{BM})+400(25 \mathrm{DAFA})$ & $980.2 \mathrm{ab}$ & 24.0 & $16.2 \mathrm{~b}$ & $11.5 \mathrm{ab}$ & 3.9 & 2.5 & 19.5 & 19.1 & 12.0 & 84 \\
\hline $\mathrm{CV}(\%)$ & 10.54 & 6.45 & 6.97 & 9.18 & 3.08 & 3.59 & 10.99 & 4.96 & 8.15 & 12.92 \\
\hline Test $\mathrm{F}$ & $3.03 *$ & $0.364^{\mathrm{NS}}$ & $5.94 * *$ & $3.82 *$ & $1.67^{\mathrm{NS}}$ & $2.30^{\mathrm{NS}}$ & $2.03^{\mathrm{NS}}$ & $0.74^{\mathrm{NS}}$ & $2.77^{\mathrm{NS}}$ & $0.04^{\mathrm{NS}}$ \\
\hline
\end{tabular}

Means within columns followed by different letters differ significantly by Tukey's test (P<0.05). NS: non-significant; *Significant $5 \%$; **Significant $1 \%$. Note: BM = beginning of the maturation; 25 DAFA = 25 days after the first application.

Table 2. Soluble solids (SS), pH, titratable acidity (TA), soluble solid relation/titratable acidity (SS/TA) and reducing sugars (RS) of grape must 'Rubi', subjected to the application of abscisic acid (S-ABA). São Miguel Arcanjo, SP, Brazil, 2014/2015.

\begin{tabular}{|c|c|c|c|c|c|}
\hline Treatments $\left(S\right.$-ABA mg L $\left.{ }^{-1}\right)$ & $\mathrm{SS}\left({ }^{\circ}\right.$ Brix $)$ & $\mathrm{pH}$ & AT (\% tartaric acid) & SS/TA & $\mathrm{RS}(\%)$ \\
\hline Control (0) & $12.3 \mathrm{~b}$ & 3.4 & $0.7 \mathrm{a}$ & $18.3 \mathrm{~b}$ & 10.3 \\
\hline $400(\mathrm{BM})$ & $13.1 \mathrm{ab}$ & 3.4 & $0.6 \mathrm{ab}$ & $23.0 \mathrm{ab}$ & 11.5 \\
\hline $400(\mathrm{BM})+200(25$ DAFA $)$ & $13.2 \mathrm{ab}$ & 3.5 & $0.5 \mathrm{~b}$ & $25.2 \mathrm{a}$ & 11.5 \\
\hline $400(\mathrm{BM})+400(25$ DAFA $)$ & $13.9 \mathrm{a}$ & 3.4 & $0.6 \mathrm{ab}$ & $25.0 \mathrm{a}$ & 11.9 \\
\hline $\mathrm{CV}(\%)$ & 6.46 & 2.12 & 17.33 & 12.81 & 6.70 \\
\hline Test $\mathrm{F}$ & $3.27 *$ & $1.44^{\mathrm{NS}}$ & $3.75 *$ & $7.06^{* *}$ & $0.14^{\mathrm{NS}}$ \\
\hline
\end{tabular}

Means within columns followed by different letters differ significantly by Tukey's test $(\mathrm{P}<0.05) .{ }^{\mathrm{NS}}$ non-significant; *Significant $5 \%$; **Significant $1 \%$.Note: BM = beginning of the maturation; 25 DAFA $=25$ days after the first application.

Table 3. Luminosity $\left(L^{*}\right)$, saturation $\left(C^{*}\right)$, hue angle $\left(h^{\circ}\right)$ and color index (CIRG) of the grape berries 'Rubi', subjected to the application of the abscisic acid (S-ABA). São Miguel Arcanjo, SP, Brazil, 2014/2015.

\begin{tabular}{lllll}
\hline Treatments & $L^{*}$ & $C^{*}$ & $h^{o}$ & CIRG \\
$(S$-ABA mg L & & & \\
\hline Control $(0)$ & $37.0 \mathrm{a}$ & $13.7 \mathrm{a}$ & $89.3 \mathrm{ab}$ & $1.8 \mathrm{~b}$ \\
$400(\mathrm{BM})$ & $30.5 \mathrm{~b}$ & $9.2 \mathrm{~b}$ & $56.6 \mathrm{~b}$ & $3.1 \mathrm{a}$ \\
$400(\mathrm{BM})+200(25$ DAFA) & $30.5 \mathrm{~b}$ & $9.3 \mathrm{~b}$ & $103.8 \mathrm{a}$ & $2.9 \mathrm{a}$ \\
$400(\mathrm{BM})+400(25 \mathrm{DAFA})$ & $30.4 \mathrm{~b}$ & $9.4 \mathrm{~b}$ & $76.7 \mathrm{ab}$ & $3.0 \mathrm{a}$ \\
\hline $\mathrm{CV}(\%)$ & 7.18 & 17.9 & 26.3 & 25.3 \\
\hline Test F & $10.82^{* *}$ & $7.99^{* *}$ & $5.19^{*}$ & $6.72^{* *}$ \\
\hline
\end{tabular}

Means within columns followed by different letters differ significantly by Tukey's test $(\mathrm{P}<0.05){ }^{\mathrm{NS}:}$ non-significant; *Significant $5 \%$; **Significant $1 \%$. Note: BM $=$ beginning of the maturation; 25 DAFA $=25$ days after the first application. 
Table 4. Anthocyanins and total phenolic compounds of the grape berries 'Rubi', subjected to the application of abscisic acid (S-ABA). São Miguel Arcanjo, SP, Brazil, 2014/2015.

\begin{tabular}{|c|c|c|}
\hline $\begin{array}{l}\text { Treatments } \\
\left(S \text {-ABA mg L }{ }^{-1}\right)\end{array}$ & 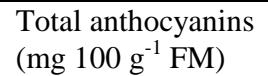 & $\begin{array}{l}\text { Total phenolic compounds } \\
\left(\mathrm{mg} 100 \mathrm{~g}^{-1} \mathrm{FM}\right)\end{array}$ \\
\hline Control (0) & $0.1 \mathrm{~b}$ & $17.00 \mathrm{~b}$ \\
\hline $400(\mathrm{BM})$ & $0.6 \mathrm{a}$ & $15.90 \mathrm{~b}$ \\
\hline $400(\mathrm{BM})+200(25 \mathrm{DAFA})$ & $0.5 \mathrm{a}$ & $23.10 \mathrm{a}$ \\
\hline $400(\mathrm{BM})+400(25 \mathrm{DAFA})$ & $0.7 \mathrm{a}$ & $22.18 \mathrm{a}$ \\
\hline $\mathrm{CV}(\%)$ & 35.35 & 61.53 \\
\hline Test $\mathrm{F}$ & $11.65 * *$ & $2.89 *$ \\
\hline
\end{tabular}

Means within columns followed by different letters differ significantly by Tukey's test $(\mathrm{P}<0.05){ }^{\mathrm{NS}:}$ non-significant; *Significant $5 \%$; ** Significant $1 \%$. Note: $\mathrm{BM}=$ beginning of the maturation; 25 DAFA $=25$ days after the first application.

Table 5. Correlation between soluble solids (SS), pH, titratable acidity (TA), soluble solid relation/titratable acidity (SS/TA), reducing sugars (RS), anthocyanins (Ant), phenolic compounds $(\mathrm{CF})$, luminosity $\left(L^{*}\right)$, saturation $\left(C^{*}\right)$, hue angle $\left(h^{\sigma}\right)$ and color index (CIRG) of the grape berries 'Rubi', subjected to the application of the abscisic acid $(S$-ABA). São Miguel Arcanjo, SP, Brazil, 2014/2015.

\begin{tabular}{|c|c|c|c|c|c|c|c|c|c|c|}
\hline & $\mathrm{pH}$ & TA & SS/TA & RS & Ant & FC & $L^{*}$ & $C^{*}$ & $h^{o}$ & CIRG \\
\hline SS & $0.554^{* *}$ & $-0.361^{\mathrm{ns}}$ & $0.784^{* * *}$ & $0.633^{* *}$ & $0.526^{* * *}$ & $-0.020^{\mathrm{ns}}$ & $-0.460^{*}$ & $-0.030^{\mathrm{ns}}$ & $-0.272^{\mathrm{ns}}$ & $0.302^{\mathrm{ns}}$ \\
\hline $\mathrm{pH}$ & & $-0.243^{\text {ns }}$ & $0.554^{* *}$ & $0.616^{* *}$ & $0.463^{*}$ & $0.094^{\mathrm{ns}}$ & $-0.423^{*}$ & $-0.248^{\mathrm{ns}}$ & $0.011^{\mathrm{ns}}$ & $0.110^{\mathrm{ns}}$ \\
\hline TA & & & $-0.826^{* *}$ & $-0.367^{\text {ns }}$ & $-0.367^{\mathrm{ns}}$ & $0.331^{\mathrm{ns}}$ & $0.288^{\text {ns }}$ & $0.235^{\mathrm{ns}}$ & $-0.077^{\text {ns }}$ & $-0.043^{\text {ns }}$ \\
\hline SS/TA & & & & $0.561^{\text {*** }}$ & $0.545^{* *}$ & $-0.205^{\mathrm{ns}}$ & $-0.480^{*}$ & $-0.252^{\mathrm{ns}}$ & $-0.037^{\mathrm{ns}}$ & $0.158^{\mathrm{ns}}$ \\
\hline RS & & & & & $0.340^{\text {ns }}$ & $0.125^{\text {ns }}$ & $-0.208^{\text {ns }}$ & $0.020^{\mathrm{ns}}$ & $-0.262^{\text {ns }}$ & $0.264^{\mathrm{ns}}$ \\
\hline Ant & & & & & & $0.008^{\text {ns }}$ & $-0.874^{* * *}$ & $-0.266^{\mathrm{ns}}$ & $-0.472^{*}$ & $0.611^{* * *}$ \\
\hline $\mathrm{FC}$ & & & & & & & $-0.034^{\mathrm{ns}}$ & $-0.290^{\mathrm{ns}}$ & $0.032^{\mathrm{ns}}$ & $-0.003^{\text {ns }}$ \\
\hline$L^{*}$ & & & & & & & & $0.464^{*}$ & $0.551^{* *}$ & $-0.732^{* * *}$ \\
\hline$C^{*}$ & & & & & & & & & $-0.029^{\mathrm{ns}}$ & $-0.222^{\text {ns }}$ \\
\hline$h^{o}$ & & & & & & & & & & $-0.955^{\text {*** }}$ \\
\hline
\end{tabular}


these when green give the impression that they are immature (acid).

\section{Anthocyanin and total phenolic compounds}

There was significant effect for the anthocyanin concentration and total phenolic compounds of berries 'Rubi' grape (Table 4). The concentration of total anthocyanins was influenced by the application of $S$-ABA, being that the values ranged from 0.5 to $0.7 \mathrm{mg} 100 \mathrm{~g}^{-1}$ of fresh mass (FM) for berries treated, while for the not treated the concentration was $0.1 \mathrm{mg} 100 \mathrm{~g}^{-1}$ of FM (Table 4). The application of $S$-ABA also increased the concentration of total anthocyanins in berries and grape juice of 'Isabel' (Koyama et al., 2014b) and the anthocyanins of 'Flame Seedless' (Peppi and Fidelibus, 2008). The same was observed for the grape 'Pionnier', with the application of abscisic acid (ABA) (Kondo et al., 1998).

The $S$-ABA also promoted significant effect for total phenolic compounds of 'Rubi' grape berries (Table 4). The treatments that received two applications, regardless of the concentration, presented the largest values (22.18 and 23.10 $\mathrm{mg} 100^{-1}$ of FM), differing from the control $\left(17.00 \mathrm{mg} 100 \mathrm{~g}^{-}\right.$ ${ }^{1}$ of FM) and treatment with only one application $(15.90 \mathrm{mg}$ $100 \mathrm{~g}^{-1}$ of FM) (Table 4). The treatments providing the best color to the bunches of grapes 'Rubi', also had the greatest values of total phenolic compounds, showing that the more intense the color of berries, the higher the content of phenolic compounds. Therefore, the grape color becomes more interesting for consumption, for showing functional characteristic.

The concentration of total phenolic compounds of Must and juice of 'Isabel' grape was not influenced by the application of $S$-ABA (Koyama et al., 2014b). Now the treatment with abscisic acid stimulated the anthocyanin accumulation and total phenolic compounds for table grape 'Alachua' and for wine 'Noble' (Sandhu et al., 2011).

\section{Correlation analysis}

Analyzing the correlation, it is verified that the levels of soluble solids (SS) presented moderate positive correlation with $\mathrm{pH}(\mathrm{r}=0.554)$, reducing sugars $(\mathrm{RS})(\mathrm{r}=0.633)$ and anthocyanins $(\mathrm{r}=0.526)$ and moderate negative with the luminosity $\left(L^{*}\right)(\mathrm{r}=-0.460)$ and strong positive with the ratio soluble solids/acidity (SS/TA), because the $\mathrm{r}$ value was 0.784 (Table 5). The $\mathrm{pH}$ also presented moderate positive correlation with SS/TA, air and anthocyanins and moderate negative with the $L^{*}$. The titratable acidity (TA) only correlated with SS/TA, considered as strong negative, similar behavior was observed in the relations of reducing sugars. However, in addition to the correlation with SS/TA, correlation with $\mathrm{SS}$ and $\mathrm{pH}$, which is moderate positive in both correlations.

The anthocyanins presented moderate positive correlation with SS, pH, SS/TA and color index (CIRG); moderate negative correlation with $h^{o}$ and strong negative with $L^{*}$. The fact of the anthocyanins has presented correlation with the attributes of color. It can be inferred that the colored grapes present larger concentrations of anthocyanins and feature pleasant flavor (evidenced by correlation with SS and SS/TA).

It was also observed a moderate correlation positive of $L^{*}$ with saturation $\left(C^{*}\right)(\mathrm{r}=0.464)$ and with $h^{\circ}(\mathrm{r}=0.551)$ and strong negative correlation with CIRG $(\mathrm{r}=-0.732)$.

The use of $S$-ABA improved the accumulation of the anthocyanins totals of berries 'Rubi' grape, especially when it was applied twice. In addition, the treatments with the application of $S$-ABA caused reduction in TA of the Must and the increase in the SS content and consequently in ratio SS/TA. These treatments also increased the total phenolic compounds concentrations of berries. Thus, the use of $S$ $\mathrm{ABA}$ is a promising alternative that implies in the increment of the commercial value of the table grape, causing greater acceptance by consumers, since these are attracted by the appearance of the berry pink color of the grape berries 'Rubi'.

\section{Materials and Methods}

\section{Location and plant materials}

The experiment was carried out in a commercial vineyard of 'Rubi' table grape (Vitis vinifera $\mathrm{L}$.) grafted on the rootstock 420-A, with the grapevines spaced at $4 \times 2 \mathrm{~m}$ and sustained in pergola system in the sixth year of production. The experiment was performed in the 2014/15 production cycle, in vineyard located in São Miguel Arcanjo, SP (2331' S, $47^{\circ} 35^{\prime} \mathrm{O}$ and average altitude of $660 \mathrm{~m}$ ), Brazil. The climate of the region, according to the Köppen classification is $C w a$, with average annual amount of rainfall of $1396 \mathrm{~mm}$, annual average temperature of $20.4{ }^{\circ} \mathrm{C}$ and relative humidity of $70.6 \%$.

The long cane pruning (6 buds) was held in August 2014, being subsequently applied hydrogenated cyanimide at $2 \%$, aiming the sproutings uniformity. After the buds sprouting, the removal of less vigorous was performed, leaving 2 to 3 shoots per branch (Roberto et al., 2012).

\section{Experimental design and treatments}

The experimental design was a randomized blocks, with 4 treatments and 6 replications. The treatments were obtained from the concentrations of isomer $S$-ABA $\left(100 \mathrm{~g} \mathrm{~L}^{-1}\right.$ of active ingredient, Valent BioSciences Co. $\left.{ }^{\circledR}\right)$ as follows: Control (0 $\left.\mathrm{mg} \mathrm{L}^{-1}\right) ; 400 \mathrm{mg} \mathrm{L}^{-1}$ of $S$-ABA in the beginning of the maturation (BM); $400 \mathrm{mg} \mathrm{L}^{-1}$ in $\mathrm{BM}+200 \mathrm{mg} \mathrm{L}^{-1}$ at 25 DAFA (25 days after the first application) and $400 \mathrm{mg} \mathrm{L}^{-1}$ in $\mathrm{BM}+400 \mathrm{mg} \mathrm{L}^{-1}$ at 25 DAFA. The non-ionic sulfactant BreakThru $^{\circledR}\left(0.3 \mathrm{~mL} \mathrm{~L}^{-1}\right)$ was added to the syrup of all treatments. It was considered as BM to the first application, softening berries and color change, which presented soluble solids values of $9^{\circ}$ Brix and acidity of $0.9 \%$ of tartaric acid. For the application of the treatments, the bunches were sprayed in the morning, using costal sprayer with pressure at $40 \mathrm{kgf}^{2}$ with nozzles tips of hollow cone jet-JA1, providing full and uniform coverage, being used syrup volume of $900 \mathrm{~L}$ $\mathrm{ha}^{-1}$.

\section{Harvest and characteristics evaluated}

The harvest was performed at 40 days after the first application of $S$-ABA, in which from each plot five bunches were harvested, and the following physical characteristics were evaluated: fresh mass, length and width of the bunches, berries and stems and number of berries per bunch. For the evaluation of these characteristics a semi-analytical balance was used with precision of $0.1 \mathrm{~g}$ with a digital caliper. The chemical characteristics of the Must were determined in a sample of 50 berries per plot as follows: content of soluble solids, $\mathrm{pH}$, titratable acidity, soluble solids/acidity ratio, according to Brasil (2005) and reducing sugar according to the methodology of Nelson (1944).

The color of the berries was evaluated in samples of 50 berries per plot, employing the Minolta colorimeter CR-10 ${ }^{\circledR}$, 
evaluating the variables of the equatorial portion of the berries: $L^{*}$ (luminosity), $C^{*}$ (saturation) and $h^{\circ}$ (hue angle) (Koyama et al., 2014a). The color index of red grapes (CIRG) was determined through the formula: $\mathrm{CIRG}=[(180-$ $\left.\left.h^{o}\right) /\left(L^{*}+C^{*}\right)\right]$ (Carreño and Martinez, 1995).

It was also determined the total concentration of anthocyanins (Lee and Francis, 1972) and total phenolic compounds of berries (Popova et al., 2004) with adjustments.

\section{Statistical analysis}

The data obtained were submitted to variance analysis (F) and the averages compared by the Tukey test at 5\% probability through the computational program SISVAR (Ferreira, 2011). A correlation analysis was performed between the contents of soluble solids, $\mathrm{pH}$, titratable acidity, soluble solids/acidity ratio, reducing sugars, anthocyanins and total phenolic compounds of the berries and color attributes $\left(L^{*}, C^{*}, h^{o}\right.$ e CIRG), performed through the program ASSISTAT (Silva and Azevedo, 2002).

\section{Conclusions}

The application of $S$-ABA caused slight effects on the physical characteristics of the bunches, berries and stems of 'Rubi' table grape. However, it significantly improved the chemical attributes of the Must, reducing the acidity and increasing the content of soluble solids and soluble solids/acidity ratio. The $S$-ABA considerably improved the color of the berries of 'Rubi' grape and provided significant increment in the anthocyanin accumulation and total phenolic compounds. In general, the application of $S$-ABA is a promising tool for the viticulture, because it adds value to the final product, mainly for the fine table grapes, especially when applied twice. Therefore, it is recommended to be applied as $400 \mathrm{mg} \mathrm{L}^{-1}$ of $S$-ABA in $\mathrm{BM}+200 \mathrm{mg} \mathrm{L}^{-1}$ at 25 DAFA, aiming to reduce expenditures in the second application.

\section{Acknowledgements}

The authors thank the producer Luiz Domingues and their family and Capes for granting scholarship.

\section{References}

AGRIANUAL-Anuário da Agricultura Brasileira (2015) UVA: produção brasileira, São Paulo: Editora FNP, p. 464.

Ban T, Ishimaru M, Kobayashi S, Goto-Yamamoto N, Horiuchi S (2003) Abscisic acid and 2,4dichlorophenoxyacetic acid affect the expression of anthocyanin biosynthetic pathway genes in 'Kyoho' grape berries. J Hort Sci Biotech. 1(78):586-589.

Brasil. Ministério da Saúde. Agência Nacional de Vigilância Sanitária (2005) Métodos físico-químicos para análise de alimentos. Brasília, 1018p.

Cantín CMA, Fidelibus BMW, Crisoto CH (2007) Application of abscisic acid (ABA) at veraison advanced red color development and maintained postharvest quality of 'Crimson Seedless' grapes. Post Biol Technol. 46(3): 237-241.

Cao M, Bai X, Li Y, Xie T, Wen R, Liu J (2010) Effect of abscisic acid on the color and fruit quality of 'Kyoho' grape. Guangd Agric Sci. 2(39): 111-113.

Carreño J, Martinez A (1995) Proposal of an index for the objective evaluation of the color of red table grape. Food Res Int. 28(4): 373-377.
Chitarra MIF, Chitarra AB (2005) Pós-colheita de frutas e hortaliças: fisiologia e manuseio. 2nd edn. Lavras, Brasil: Editora UFLA, 785p.

Ferreira DF (2011) Sisvar: a computer statistical analysis system. Cien e Agrotec. 35(6): 1039-1042.

Gardin JPP, Schumacher RL, Bettoni JC, Petri JL, Souza EL (2012) Ácido abscísico e etefom: influência sobre a maturação e qualidade das uvas 'Cabernet Sauvignon'. Rev Bras Frutic. 34(2): 321-327.

Han DH, Lee SM, Kim SB (1996) Effects of ABA and ethephon treatments on coloration and fruit quality in 'Kyoho' grape. J Kor Soc Hort Sci. 37(3): 416-420.

Hiratsuka S, Onodera H, Kawai Y, Kubo T, Itoh H, Wada R (2001) ABA and sugar effects on anthocyanin formation in grape berry cultured in vitro. Sci Hort. 90(1): 121-130.

Jeong ST, Uoto NG, Kobayashi S, Esaka M (2004) Effects of plant hormones and shading on the accumulation of anthocyanins and the expression of anthocyanin biosynthetic genes in grape berry skins. Plant Sci. 167(2): 247-252.

Kataoka A, Sugiura N, Utsunomiya T (1982) Effect of abscisic acid and defoliation on anthocyanin accumulation in 'Kyoho' grapes (Vitis vinifera L. x V. labruscana BAILEY). Vitis. 2(1): 325-332.

Kondo S, Masuda E, Inoue K (1998) Relation between ABA application and fruit quality of 'Pionnier' grape (Vitis sp.). Acta Hort. 464(130): 35-40.

Koyama R, Assis AM, Yamamoto LY, Borges WF, Borges RS, Roberto SR (2014a) Exogenous abscisic acid increases the anthocyanin concentration of berry and juice from 'Isabel' grapes (Vitis labrusca L.). HortScience. 49(4): 460-464.

Koyama R, Yamamoto LY, Borges WF, Pascholati MB, Borges RS, Assis AM, Roberto SR (2014b) Épocas de aplicação e concentrações de ácido abscísico no incremento da cor da uva 'Isabel'. Semina: Cienc Agrar. 35(4): $1697-$ 1706.

Koyama R, Assis AM, Yamamoto LY, Prudencio SH, Roberto SR (2015) Análise sensorial do suco integral de uva 'Isabel' submetida à aplicação de ácido abscísico. Rev Bras Frutic. 37(4): 893-901.

Leão PCS, Coelho Lima MA, Costa JPD, Trindade DCG (2014) Abscisic Acid and Ethephon for Improving Red Color and Quality of Crimson Seedless Grapes Grown in a Tropical Region. Amer J Enol Vitic. 66(1): 37-45.

Lee DH, Francis FJ (1972) Standardization of pigment analyses in cranberries. HortScience. 7(1): 83-84.

Lee JC, Tomana $\mathrm{T}$ (1980) Physiological study on anthocyanin development in grapes. II. Effect of sucrose, abscisic acid and indoleacetic acid on the anthocyanin development in 'Kyoho' grape (Vitis labruscana). J Kor Soc Hort Sci. 21(1): 158-163.

Matsushima J, Hiratsuka S, Taniguchi N, Wada R, Suzaki N (1989) Anthocyanin accumulation and sugar content in the skin of grape cultivar Olympia treated with ABA. J Jpn Soc Hort Sci. 58(1): 551-555.

Nelson NA (1994) A photometric adaptation of Somogyi method for the determination of glucose. J Biol Chem. 135(1): 136-175.

Owen SJ, Lafond MD, Bowen P, Bogdanoff C, Usher K, Abrams SR (2009). Profiles of abscisic acid and its catabolites in developing Merlot grape (Vitis vinifera) berries. Amer J Enol Vitic. 60(1): 277-284.

Peppi MC, Fidelibus MW (2008) Effects of forchlorfenuron and abscisic acid on the quality of 'Flame Seedless' grapes. HortScience. 43(1): 173-176. 
Peppi MC, Fidelibus MW, Dokoozlian N (2006) Abscisic acid application timing and concentration affect firmness, pigmentation, and color of 'Flame Seedless' grapes. Sci Hort. 41(6): 1440-1445.

Peppi MC, Fidelibus MW, Dokoozlian N (2007) Application timing and concentration of abscisic acid affect the quality of 'Redglobe' grapes. J Hort Sci Biotech. 82(2): 304-310.

Pommer CV, Terra MM, Pires EJP (2003) Cultivares, melhoramento e fisiologia. In: Pommer CV (ed) Uva: tecnologia de produção, pós-colheita, mercado. Porto Alegre, Brasil, Editora: Cinco Continentes, 778p.

Popova M, Bankova V, Butovska D, Petkov V, NikolovaDamyanova B, Sabatini AG, Marcazzan GL, Bogdanov S (2004) Validated methods for the quantification of biologically active constituents of poplar-type propolis. Phytoch Analysis. 15(4): 235-240.

Ribichaud JL, Noble AC (1990) Astringency and bitterness of selected phenolic in wines. J Sci Food Agric. 53(3): 343353.

Roberto SR, Assis AM, Yamamoto LY, Miotto LCV, Sato AJ, Koyama R, Genta W (2012) Application timing and concentration of abscisic acid improve color of 'Benitaka' table grape. Sci Hort. 142(1): 44-48.

Roberto SR, Assis AM, Yamamoto LY, Miotto LCV, Koyama R, Sato AJ, Borges RS (2013) Ethephon use and application timing of abscisic acid for improving color of 'Rubi' table grape. Pesq Agropec Bras. 48(7): 797-800.
Sandhu AK, Gray DJ, Lu J, Gu L (2011) Effects of exogenous abscisic acid on antioxidant capacities, anthocyanins and flavonol contents of muscadine grape (Vitis rotundifolia) skins. Food Chem. 126 (3): 982-988.

Silva FAS, Azevedo CAV (2002) Versão do programa computacional ASSISTAT para o sistema operacional Windows. Rev Bras Prod Agroind. 4 (1): 71-78.

Terra MM, Pires EJP, Nogueira NAM (1998) Tecnologia para produção de uva 'Itália' na região noroeste do estado de São Paulo. Campinas: Coordenadoria de Assistência Técnica Integral, 81p.

Yamamoto LY, Assis AM, Roberto SR, Bovolenta YR, Nixdorf SL, García-Romero E, Gómez-Alonso S, Hermosín-Gutiérrez I (2015a) Application of abscisic acid $(S$-ABA) to $\mathrm{cv}$. Isabel grapes (Vitis vinifera $\times$ Vitis labrusca) for color improvement: Effects on color, phenolic composition and antioxidant capacity of their grape juice. Food Res Int. 77(3): 572-583.

Yamamoto LY, Koyama R, Assis AM, Borges WS, Oliveira IRO, Roberto SR (2015b) Color of berry and juice of 'Isabel' grape treated with abscisic acid in different ripening stages. Pesq Agropec Bras. 50(12): 1160-1167. 